\title{
EFFICIENCY OF NITROGEN FERTILIZER APPLIED AT CORN SOWING IN CONTRASTING GROWING SEASONS IN PARAGUAY ${ }^{(1)}$
}

\author{
Telmo Jorge Carneiro Amado ${ }^{(2)}$, Enrique Oswin Hahn Villalba ${ }^{(3)}$, Rafael Pivotto \\ Bortolotto $^{(4)}$, Antônio Luis Santi ${ }^{(5)}$, Enrique Asterio Benítez León ${ }^{(6)}$, Dorothy Menefee ${ }^{(7)}$ \\ \& Junior Kunz ${ }^{(8)}$
}

\begin{abstract}
SUMMARY
In order to select soil management practices that increase the nitrogen-use efficiency (NUE) in agro-ecosystems, the different indices of agronomic fertilizer efficiency must be evaluated under varied weather conditions. This study assessed the NUE indices in no-till corn in southern Paraguay. Nitrogen fertilizer rates from 0 to $180 \mathrm{~kg} \mathrm{ha}^{-1}$ were applied in a single application at corn sowing and the crop response investigated in two growing seasons (2010 and 2011). The experimental design was a randomized block with three replications. Based on the data of grain yield, dry matter, and $\mathrm{N}$ uptake, the following fertilizer indices were assessed: agronomic $\mathrm{N}$-use efficiency (ANE), apparent $\mathrm{N}$ recovery efficiency (NRE), $\mathrm{N}$ physiological efficiency (NPE), partial factor productivity (PFP), and partial nutrient balance (PNB). The weather conditions varied largely during the experimental period; the rainfall distribution was favorable for crop growth in the first season and unfavorable in the second. The PFP and ANE indices, as expected, decreased with increasing $\mathbf{N}$ fertilizer rates. A general analysis of the $\mathbf{N}$ fertilizer indices in the first season showed that the maximum rate $\left(180 \mathrm{~kg} \mathrm{ha}^{-1}\right)$ obtained the highest corn yield and also optimized the efficiency of NPE, NRE and ANE. In the
\end{abstract}

(1) Part of the Thesis of the second author presented of the Graduate Course of Agricultural Engineering, Federal University of Santa Maria, UFSM. Received for publication on December 11, 2012 and approved on August 20, 2013.

(2) Full Professor, Department of Soil Science - DSS, UFSM. Av. Roraima, 1000. CEP 97105-900 Santa Maria (RS). Scholarship CNPq. E-mail: telmo.amado@pesquisador.cnpq.br

(3) Doctoral student in Agricultural Engineering, UFSM. Scholarship CAPES. E-mail: enriqueohahn@hotmail.com

(4) Researcher, DSS, UFSM. E-mail: rpbortolotto@yahoo.com.br

(5) Adjunct Professor, Centro de Educação Superior Norte do Rio Grande do Sul - CESNOR, UFSM. Linha Sete de Setembro, s/ n, BR 386 km 40. CEP 98400-000 Frederico Westphalen (RS). E-mail: santi_pratica@yahoo.com.br

(6) Researcher at Universidad Nacional de Asunción. Bairro Campus, km 10. CEP 1039 San Lorenzo, Paraguay. E-mail: enriqueleon@hotmail.com

(7) Undergraduate student, Kansas State University, Throckmorton Plant Science Center, 2004. ZipeCode 66506 Manhattan, USA. Scholarship CAPES/FIPSE. E-mail: dorothym@k-state.edu

(8) Master student in Agricultural Engineering, UFSM. Scholarship CAPES. E-mail: junioragrokunz@gmail.com 


\begin{abstract}
second season, under water stress, the most efficient $\mathrm{N}$ fertilizer rate $\left(60 \mathrm{~kg} \mathrm{ha}^{-1}\right)$ was three times lower than in the first season, indicating a strong influence of weather conditions on NUE. Considering that weather instability is typical for southern Paraguay, anticipated full $\mathrm{N}$ fertilization at corn sowing is not recommended due the temporal variability of the optimum $\mathrm{N}$ fertilizer rate needed to achieve high ANE.
\end{abstract}

Index terms: Zea mays, plant nutrition, no-tillage, soil fertility.

\title{
RESUMO: EFICIÊNCIA DA FERTILIZAÇÃO NITROGENADA APLICADA NA SEMEADURA DO MILHO, AVALIADA SOB CONDIÇÕES CLIMÁTICAS CONTRASTANTES NO PARAGUAI
}

\begin{abstract}
Visando selecionar práticas de manejo que incrementem a eficiência do uso de nitrogênio (EUN) em agroecossistemas, faz-se necessário avaliar vários índices agronômicos de eficiência da fertilização. O objetivo deste trabalho foi avaliar a EUN no milho, sob sistema plantio direto na região Sudeste do Paraguai. Neste trabalho, investigou-se a fertilização integral na semeadura do milho com doses variando de 0 até $180 \mathrm{~kg}$ de $\mathrm{N}$, durante duas safras (2010e 2011). O delineamento foi de blocos ao acaso, com três repetições. Com os dados de produtividade de grãos e matéria seca o $N$ absorvido, realizaram-se os cálculos dos seguintes índices: eficiência agronômica do uso de $N(E A N)$, eficiência aparente da recuperação de $N(E R N)$, eficiência fisiológica do $N(E F N)$, produtividade parcial do fator (PPF) e balanço parcial do nutriente (BPN). As condições climáticas foram favoráveis ao desenvolvimento da cultura do milho na primeira safra e desfavoráveis na segunda. Os índices PPF e EAN, conforme esperado, apresentaram valores decrescentes em razão do incremento das doses de $N$. Na análise conjunta dos índices, observou-se, na primeira safra, que com a dose máxima (180 kg ha-1) obteve-se a maior produtividade e também alcançaram-se índices eficientes de EFN, ERN e EAN. Já na segunda, a dose de $N$ mais eficiente (60 $\left.\mathrm{kg} \mathrm{ha}^{-1}\right)$ foi três vezes menor do que a primeira, indicando forte influência das condições climáticas sobre a EUN. Com isso, dada a variabilidade temporal das condições climáticas do Sudeste do Paraguai, a fertilização nitrogenada antecipada no milho não seria recomendada por causa da variabilidade temporal da dose de Nótima, que visa alcançar elevada EAN.
\end{abstract}

Termos de indexação: Zea mays, nutrição de plantas, plantio direto, fertilidade do solo.

\section{INTRODUCTION}

Corn productivity is markedly influenced by crop management practices and the technological level adopted, particularly the nitrogen $(\mathrm{N})$ fertilization strategy. South American countries are generally characterized by a large range of crop management levels, from low input subsistence agriculture to highinput commercial farms. As a result, the average corn $\mathrm{N}$ fertilization rate is an intermediate value of these two contrasting scenarios, generally ranging between 40 and $60 \mathrm{~kg} \mathrm{ha}^{-1}$. This fact may explain the lower average corn yield in this region when compared to developed countries, where corn management is more uniform (Melgar, 2006). However recently, significant corn yield increases were observed in fields with the adoption of new technologies, especially those that improve the plant population and $\mathrm{N}$ fertilizer strategy. According to Amado et al. $(2000,2002)$ and Fontoura $\&$ Bayer (2009), the optimum $\mathrm{N}$ fertilizer rate drives the development of corn plants, by increasing leaf area and photosynthesis rate. This results in higher dry matter productivity and higher grain yield.
Currently, under the global pressure to increase grain yield while simultaneously minimizing environmental risks, the $\mathrm{N}$ fertilizer efficiency in different agro-ecosystems has become a relevant issue (Amado et al., 2002; García, 2009). Nitrogen is one of the nutrients with complex environmental interactions and losses that generate economic and environmental threats. The risk of $\mathrm{N}$ loss and subsequent environmental problems depends on: soil type, weather, crop management, and $\mathrm{N}$ rate and source (Cantarella \& Montezano, 2010).

Worldwide, the average nitrogen-use efficiency (NUE) for the major cereal grains corn, wheat, rice and sorghum is around $33 \%$ (range of 29-42\%), depending on the $\mathrm{N}$ source, crop management, and technological adoption (Raun \& Johnson, 1999). In Brazil, studies with labeled $\mathrm{N}$ have shown that a significant quantity of $\mathrm{N}$ fertilizer input is not recovered by soil or plants. Therefore, depending on the environmental conditions and crop management practices, only 15 to $40 \%$ of $\mathrm{N}$ fertilizer input is recovered by the soil-plant system (Coelho et al. 1991; Gava, 2002; Lara Cabezas et al. 2005; Acosta et al., 
2011). Nevertheless, the frequently reported high correlation between plant $\mathrm{N}$ uptake and corn grain yield justifies $\mathrm{N}$ fertilization (Amado et al., 2000; Rambo et al., 2011). In rainfed systems, the recommended $\mathrm{N}$ fertilization is generally up to $100 \mathrm{~kg} \mathrm{ha}^{-1}$, and up to $160 \mathrm{~kg} \mathrm{ha}^{-1}$ for irrigated areas (Souza et al., 2003; Amaral Filho et al., 2005; Gross et al., 2006; Pavinato et al., 2008). Currently, in Brazil and Paraguay there is a trend of increasing corn $\mathrm{N}$ fertilization. Despite this trend, studies on $\mathrm{N}$ fertilization efficiency in the main agricultural regions of Paraguay are still scarce.

Among the alternatives for improving NUE, the timing of fertilizer application is important. Early fertilization in no-till crops can offset $\mathrm{N}$ immobilization caused by soil microorganisms during crop residue decomposition, meeting the $\mathrm{N}$ needs of the microbial decomposers and of corn (Sá et al., 1996; Wolschick et al., 2003). The efficiency of $\mathrm{N}$ fertilization at sowing can vary largely depending on the $\mathrm{N}$ rate, weather, and crop management practices (Ceretta et al., 2002; Nascimento et al., 2012). Pre-sowing corn N fertilizer has attracted interest from farmers because it has some operational advantages in relation to the topdressing fertilization strategy, such as: increased corn sowing efficiency, reduction of time and labor, lower machinery cost, reduction of production costs, decreased $\mathrm{N}$ volatilization loss, better crop establishment, and less plant damage by machinery in the late crop stages (Yamada \& Abdalla, 2000; Coelho et al., 2002).

In Brazilian Soil Science studies, some addressed anticipated corn $\mathrm{N}$ fertilization. Bortolini et al. (2001) found lower corn yield when $\mathrm{N}$ was applied at sowing, compared to $\mathrm{N}$ topdressing under a high rainfall regime. Cantarella et al. (2003) observed that presowing $\mathrm{N}$ fertilization reduced corn grain yield in relation to $\mathrm{N}$ topdressing when rainfall was evenly distributed. However, when rain was scarce, similar grain yields were observed for the two $\mathrm{N}$ fertilization strategies. For Wolschick et al. (2003), split applications of smaller quantities of $\mathrm{N}$ fertilizer during the corn physiological stages produce similar grain yields as early $\mathrm{N}$ application, whereas the risk of nitrate leaching into groundwater is lower, especially in years with excessive rainfall. Yamada \& Abdalla (2000) and Gomes et al. (2007) reported that early N fertilization was an efficient strategy for corn production. According to Bertolini et al. (2008), the highest corn yield in no-till systems is generally obtained when $\mathrm{N}$ fertilizer is applied at sowing. In Paraguay there is a gap of information regarding this issue. Soils and climatic conditions in Paraguay are different from those in Brazil and thus the optimal $\mathrm{N}$ fertilization practices may be different.

Cooke (1987) defined NUE as the increase in crop yield per kg-1 of $\mathrm{N}$ fertilizer input Currently, to select the best management practices for improving NUE, Snyder \& Bruuselma (2007) and Dobermann (2007) proposed five agronomic indices to characterize the efficiency of $\mathrm{N}$ fertilizer programs. These indices should be validated for each ecoregion, technological level, and crop management system. This study evaluated the different agronomic fertilizer indices for characterizing NUE for no-till corn under varied weather conditions in southern Paraguay.

\section{MATERIAL AND METHODS}

This study was carried out in southern Paraguay, in one of most important agricultural regions of the country. The climate classified as Cfa by Köppen, i.e., humid subtropical, mesothermal, with hot summers and occasional frost in the winter. The average annual rainfall ranges from 1,300 to $1,900 \mathrm{~mm}$, with rainfall evenly distributed throughout the year. Temperature average ranges from 17 to $27^{\circ} \mathrm{C}$ in the months of July and January, respectively.

This study investigated NUE in an experiment over two consecutive growing seasons (2010 and 2011). The experimental area is located in Alto Verá, Itapúa Department, on a farm owned by a member of the Farm Cooperative United Colonies (www.colonias.com.py). The region is notable for grain production of for example soybean, corn, wheat, oat, sunflower, and sorghum. The soil of the experiment was a Hapludox with clayey-loam texture. Table 1 shows the soil characteristics evaluated by procedures described by Tedesco et al. (1995).

The experiment was rainfed, and in the 2010 growing season the total rainfall was high - $359 \mathrm{~mm}$ from 55 days after sowing (DAS) until maturation. In 2011 the rainfall was lower, with a dry spell during critical growth stages and rainfall of $141 \mathrm{~mm}$ from 55 DAS until physiological maturation (Figure 1).

The experimental design was a randomized block with three replications. The plot size was $10 \times 5 \mathrm{~m}$. The following $\mathrm{N}$ fertilizer rates were tested: $0,30,60$, 90,120 , and $180 \mathrm{~kg} \mathrm{ha}^{-1}$. All $\mathrm{N}$ fertilizer rates were applied by broadcasting the full amount on the soil surface at corn sowing. The $\mathrm{N}$ fertilizer source was urea.

Table 2 shows the corn plant evaluations. In order to evaluate the quantity of $\mathrm{N}$ uptake at tasseling, 10 corn plants were collected from the two central rows of each plot. The sampled plants were dried at $65^{\circ} \mathrm{C}$ to constant weight. The plant $\mathrm{N}$ content was obtained by digesting $0.2 \mathrm{~g}$ dry matter with $\mathrm{H}_{2} \mathrm{SO}_{4}$ and a digestion mixture $\left(\mathrm{Na}_{2} \mathrm{SO}_{4}, \mathrm{CuSO}_{4} \cdot 5 \mathrm{H}_{2} \mathrm{O}\right)$, followed by semi-micro Kjeldahl steam distillation as described by Tedesco et al. (1995).

Corn grain yield was determined after handharvesting the four central rows of each plot, disregarding $0.5 \mathrm{~m}$ at either end (borders), resulting in a total harvested area of $16 \mathrm{~m}^{2}$ per plot. The grain yield was adjusted to $14 \%$ moisture. Based on grain 
Table 1. Characterization of soil fertility at begins of the experiment, in two soil layers

\begin{tabular}{|c|c|c|c|c|c|c|c|c|c|}
\hline Depht & Clay $^{(1)}$ & $\operatorname{SOM}^{(2)}$ & $\mathrm{pH}\left(\mathrm{H}_{2} \mathrm{O}\right)$ & $\mathbf{P}^{(3)}$ & $\mathbf{K}^{(3)}$ & $\mathrm{Ca}^{2+(4)}$ & $\mathrm{Mg}^{2+(4)}$ & $\mathrm{Al} 3^{+(4)}$ & $\operatorname{CEC}^{(5)}$ \\
\hline $\mathrm{m}$ & - & 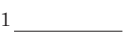 & & $\mathrm{mg} \mathrm{dm}{ }^{-3}$ & 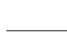 & 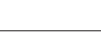 & $\mathrm{amol}_{\mathrm{c}} \mathrm{dm}$ & & \\
\hline $0-0.10$ & 441 & 33 & 5.7 & 6.09 & 1.2 & 45.4 & 13.2 & 0.0 & 99.0 \\
\hline $0-0.20$ & 449 & 32 & 5.3 & 5.50 & 1.1 & 43.6 & 12.6 & 0.2 & 112.0 \\
\hline
\end{tabular}

(1) Evaluated by densimetry; ${ }^{(2)}$ Soil organic matter: evaluated by Walkley-Black; ${ }^{(3)}$ extracted by Mehlich-1; ${ }^{(4)}$ extracted by $\mathrm{KCl}\left(1 \mathrm{~mol} \mathrm{~L}^{-1}\right)$; ${ }^{(5)}$ cation exchange capacity.

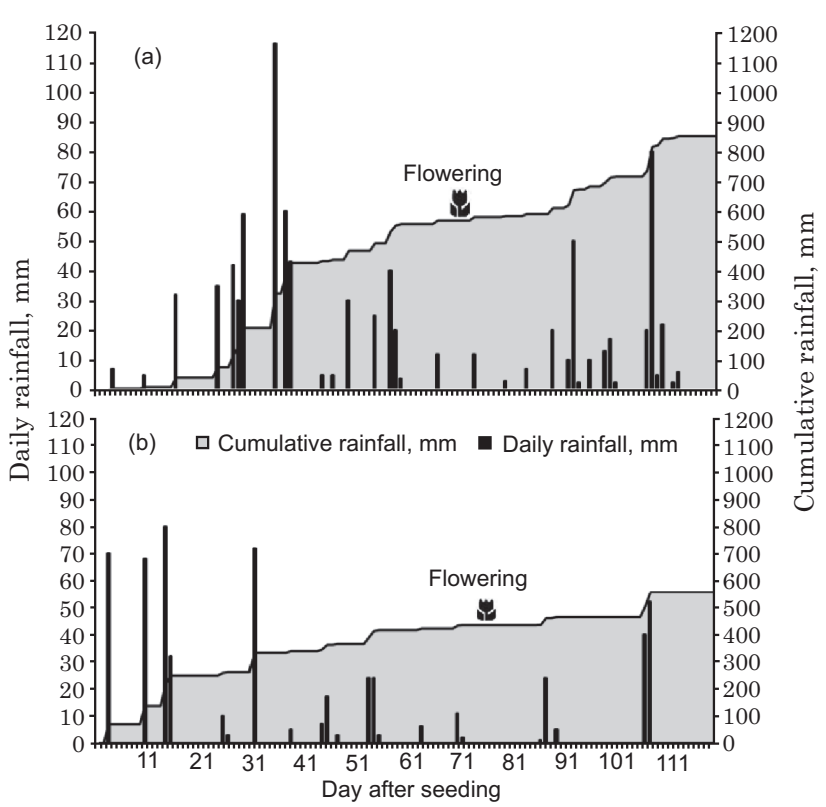

Figure 1. Day and cumulative rainfall experimental area during corn growing season in 2010 (a) and 2011 (b), in Alto Verá, Paraguay.

Table 2. Characteristics of the experiments

\begin{tabular}{lc}
\hline \multicolumn{2}{c}{ Characteristic } \\
\hline Coordinate & S 26 $6^{\circ} 42^{\prime} 43.20^{\prime \prime} ;$ W $55^{\circ} 44^{\prime} 45.6^{\prime \prime}$ \\
Altitude & $310 \mathrm{~m}$ \\
No-till adoption & 12 years \\
Corn hybrid & DKB 390 (Dekalb) \\
Previous crop & Wheat \\
Sowing date 2010 season & Nov. 06, 2010 \\
Sowing date 2011 season & Sept. 29, 2011 \\
Harvest date 2010 season & March 29, 2011 \\
Harvest date 2011 season & February 16, 2012 \\
P (Super phosphate triple) & $90 \mathrm{~kg} \mathrm{ha}^{-1}$ \\
K (Chloride potassium) & $60 \mathrm{~kg} \mathrm{ha}^{-1}$ \\
Row spacing (m) & $0.70 \mathrm{~m}^{-1}$ \\
Crop density 2010 season & 59,000 plants ha $^{-1}$ \\
Crop density 2011season & 55,000 plants ha $^{-1}$ \\
\hline
\end{tabular}

yield, dry biomass production, and corn $\mathrm{N}$ uptake quantity; five $\mathrm{N}$ fertilizer indices were calculated using the method proposed by Snyder \& Bruuselma (2007) and Dobermann (2007). The indices were as follows: partial factor productivity $(\mathrm{PFP}=\mathrm{kg}$ of grain yield/ $\mathrm{kg}$ of nutrient input), agronomic nitrogen-use efficiency (ANE $=\mathrm{kg}$ of increase in grain yield $/ \mathrm{kg}$ of nutrient supplied), apparent $\mathrm{N}$ recovery efficiency $(\mathrm{NRE}=\mathrm{kg}$ of nutrient uptake/kg of nutrient input), partial nutrient balance $(\mathrm{PNB}=\mathrm{kg}$ of nutrient exported/kg of nutrient input) and $\mathrm{N}$ physiological efficiency (NPE $=\mathrm{kg}$ of increase in grain yield $/ \mathrm{kg}$ of nutrient uptake). These indices are shown in equations 1, 2, 3, 4, and 5, respectively:

$$
\begin{gathered}
\mathrm{PFP}=\mathrm{Y}_{\mathrm{N}} / \mathrm{X}_{\mathrm{N}} \\
\mathrm{ANE}=\left(\mathrm{Y}_{\mathrm{N}}-\mathrm{Y}_{\mathrm{C}}\right) / \mathrm{X}_{\mathrm{N}} \\
\mathrm{NRE}=\left(\mathrm{NU}_{\mathrm{N}}-\mathrm{NUc}\right) / \mathrm{X}_{\mathrm{N}} \\
\mathrm{PNB}=\mathrm{E}_{\mathrm{N}} / \mathrm{X}_{\mathrm{N}} \\
\mathrm{NPE}=\left(\mathrm{Y}_{\mathrm{N}}-\mathrm{Y}_{0}\right) /\left(\mathrm{NU}_{\mathrm{N}}-\mathrm{NU}_{\mathrm{C}}\right)
\end{gathered}
$$

Where: $\mathrm{Y}_{\mathrm{N}}=$ corn grain yield in $\mathrm{N}$ fertilizer treatment; $\mathrm{Y}_{\mathrm{C}}=$ corn grain yield in the control treatment (no $\mathrm{N}$ fertilizer); $\mathrm{X}_{\mathrm{N}}=$ quantity of $\mathrm{N}$ fertilizer input; $\mathrm{NU}_{\mathrm{N}}=$ quantity of $\mathrm{N}$ uptake at flowering in $\mathrm{N}$ fertilizer treatment; $\mathrm{NU}_{\mathrm{C}}=$ quantity of $\mathrm{N}$ uptake at flowering in the control treatment (no $\mathrm{N}$ fertilizer); and $\mathrm{E}_{\mathrm{N}}=$ quantity of $\mathrm{N}$ exported at harvest.

Results were subjected to analysis of variance by the program SISVAR 5.3 (Ferreira, 2010), using the Tukey test at $5 \%$. Regression analysis was performed by JMP IN ${ }^{\circledR}$ software Version 3.2.1 (Sall et al., 2005), using the $\mathrm{F}$ test at $5 \%$ significance.

\section{RESULTS AND DISCUSSION}

\section{Effect of $\mathrm{N}$ fertilization on corn $\mathrm{N}$ uptake and grain yield}

Due to the occurrence of high rainfall $(852 \mathrm{~mm})$ in the experiment of the 2010 growing season, and lower precipitation $(559 \mathrm{~mm}$ ) in 2011 , the conditions of corn plant growth varied and therefore, the responses to $\mathrm{N}$ fertilization rates differed according to the growing season. The rainfall in the experimental period was higher and lower, in the first and second growing season respectively, compared to normal rainfall levels (Schmidt, 2009). Thus, in the 2010 growing season precipitation was $35 \%(+221 \mathrm{~mm})$ above normal rainfall, and in $201125 \%(-185 \mathrm{~mm})$ below this reference.

In the treatment without $\mathrm{N}$ fertilizer (control) the soil was the main $\mathrm{N}$ source for plants. In the 2010 
growing season the $\mathrm{N}$ uptake in the control was $148 \mathrm{~kg} \mathrm{ha}^{-1}$ and corn grain yield $8657 \mathrm{~kg} \mathrm{ha}^{-1}$, while in 2011, $\mathrm{N}$ uptake was $70 \mathrm{~kg} \mathrm{ha}^{-1}$ and grain yield $3226 \mathrm{~kg} \mathrm{ha}^{-1}$ (Figure 2). Therefore, pluvial precipitation and soil water availability had a marked influence on corn $\mathrm{N}$ uptake and consequently on the grain yield. In 2010, the corn grain yield without $\mathrm{N}$ fertilization was high, approaching the double of the average yield in Paraguay (4,746 $\left.\mathrm{kg} \mathrm{ha}^{-1}\right)$ (Capeco, 2011). This positive result is probably related to the long-term adoption of no-till, which allowed a recovery of soil organic matter (SOM) (Amado et al., 2002; Bayer et al., 1998, 2009), which improved the soil fertility status (Table 1). In the absence of $\mathrm{N}$ fertilization, SOM is the main source of $\mathrm{N}$ for plants (Aita \& Giacomini, 2003). Previously, Amado et al. (2000) reported that long-term no-tillage adoption increases the potentially mineralizable soil $\mathrm{N}$. In contrast, under drought the corn grain yield was $32 \%$ below the national average in 2011.

Figure 2 a shows different responses to $\mathrm{N}$ fertilization in plant $\mathrm{N}$ uptake and corn grain yield according to the growing season. The relationship of $\mathrm{N}$ fertilization and corn $\mathrm{N}$ uptake was adjusted with linear regression $\left(\mathrm{R}^{2}=0.84 ; \mathrm{p}=0.023\right.$ for the 2010 season; $R^{2}=0.76 ; p<0.0001$ for 2011) (Figure 2a). The effect of $\mathrm{N}$ fertilization increase on corn $\mathrm{N}$ uptake was confirmed, as expected, regardless of the growing season. However, in the 2010 growing season, when
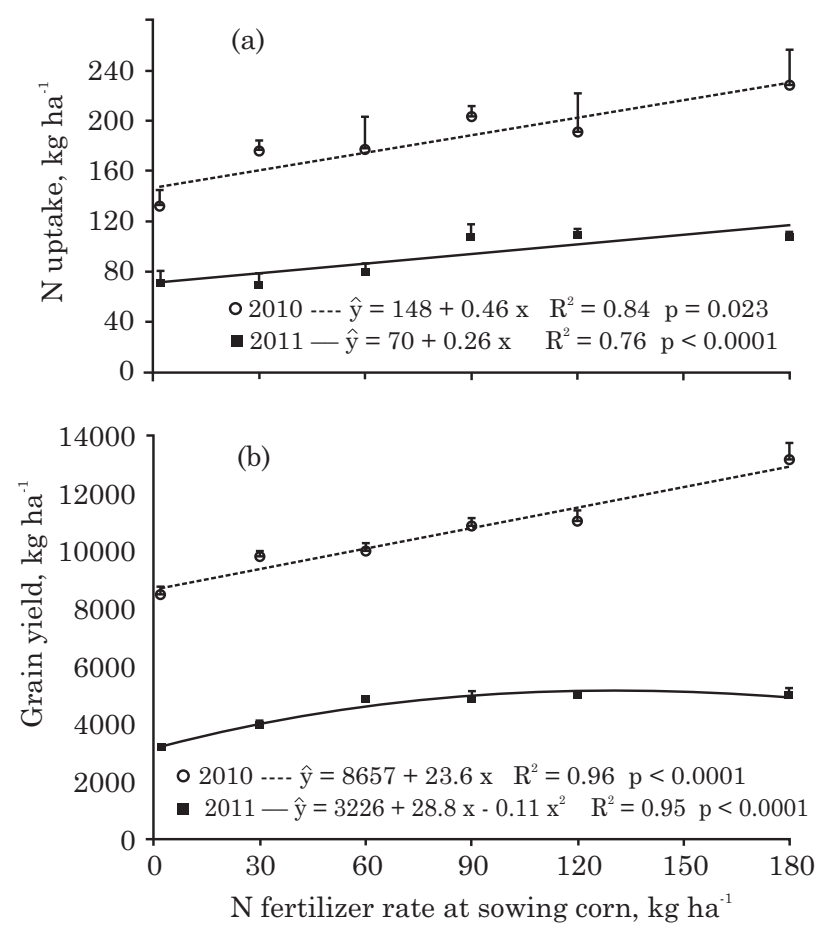

Figure 2. Nitrogen uptake (a) and corn grain yield (b) and affected by nitrogen fertilization rate in the 2010 and 2011 growing seasons. The mean values of the date are shown with error bars that shown the uncertaintly of the measurement. climatic conditions were favorable, there was an increase of $0.46 \mathrm{~kg}$ of corn $\mathrm{N}$ uptake per kg-1 of N fertilization, and only $0.26 \mathrm{~kg} \mathrm{~kg}^{-1}$ in 2011 growing season, when weather conditions were unfavorable. This result reveals the marked influence of weather conditions on corn $\mathrm{N}$ uptake in response to $\mathrm{N}$ fertilization. So while the corn nutritional status was improved in both years by $\mathrm{N}$ fertilization, the magnitude of the response was very different, being $77 \%$ higher in the first growing season compared to the second.

In the experiment of the 2010 growing season, a linear fit $\left(R^{2}=0.96 ; p<0.0001\right)$ of the corn grain yield to $\mathrm{N}$ fertilizer rates was observed (Figure $2 \mathrm{~b}$ ), with a yield increase of up to $49 \%$ at the highest $\mathrm{N}$ rate, compared with the control treatment. However, in the experiment of 2011, the grain yield response had a quadratic fit $\left(\mathrm{R}^{2}=0.95 ; \mathrm{p}<0.0001\right)$, with the grain yield reaching a maximum of $5,111 \mathrm{~kg} \mathrm{ha}^{-1}$ at an $\mathrm{N}$ rate of $131 \mathrm{~kg} \mathrm{ha}^{-1}$, representing an increase of $58 \%$ compared to the control treatment. In this crop season the treatments with $\mathrm{N}$ rates above $60 \mathrm{~kg} \mathrm{ha}^{-1}$ grain yield did not differ from each other. As the plant $\mathrm{N}$ uptake was increased with $\mathrm{N}$ fertilizer rates above of $60 \mathrm{~kg} \mathrm{ha}^{-1}$, some of the $\mathrm{N}$ taken up by plants was not converted into grain mass, due to water stress conditions. The higher grain yield in the first growing season was most likely related to higher soil water availability associated with higher precipitation, a fact that resulted in a higher probability of response to $\mathrm{N}$ fertilization (Gadioli et al., 2000).

\section{Effect of $\mathrm{N}$ fertilization on PFP and ANE}

The PFP index is calculated based on corn grain yield per unit of $\mathrm{N}$ fertilization. In both years, the linear regression was adjusted $\left(\mathrm{R}^{2}=0.72 ; \mathrm{p}<0.0001\right.$ and $\mathrm{R}^{2}=0.83 ; \mathrm{p}<0.0001,2010$ and 2011 growing seasons, respectively) for the relationship of $\mathrm{N}$ fertilizer rate and PFP (Figure 3a). As the $\mathrm{N}$ fertilizer rate was increased, there was a decrease in PFP, indicating a gradual loss of $\mathrm{N}$ efficiency. Therefore PFP was higher at low $\mathrm{N}$ rates, as expected. In the 2010 and 2011 growing seasons, $\mathrm{N}$ rates of $30 \mathrm{~kg} \mathrm{ha}^{-1}$ led to high PFP values, being 254 and $110 \mathrm{~kg} \mathrm{~kg}^{-1}$ grain yield per unit $\mathrm{N}$ input, respectively. In contrast, under high $\mathrm{N}$ rates $\left(180 \mathrm{~kg} \mathrm{~N} \mathrm{ha}^{-1}\right)$ there was a decrease in PFP with a grain yield of 29 and $14 \mathrm{~kg} \mathrm{~kg}^{-1}$ per unit $\mathrm{N}$ input in the 2010 and 2011 growing seasons, respectively. For each unit of $\mathrm{N}$ fertilization there was a decrease of 1.50 and 0.64 in PFP, in the 2010 and 2011 growing seasons, respectively. These results were affected by weather conditions, with lower values under dry than wet conditions. Rillo \& Richmond (2006) reported similar results with $\mathrm{N}$ rates from 50 to $220 \mathrm{~kg} \mathrm{ha}^{-1}$ applied at corn sowing in Argentina, resulting in PFP ranging from 360 to $55 \mathrm{~kg} \mathrm{~kg}^{-1}$, respectively.

Under low $\mathrm{N}$ fertilizer rates, there was a large difference in the PFP index between seasons, but at 

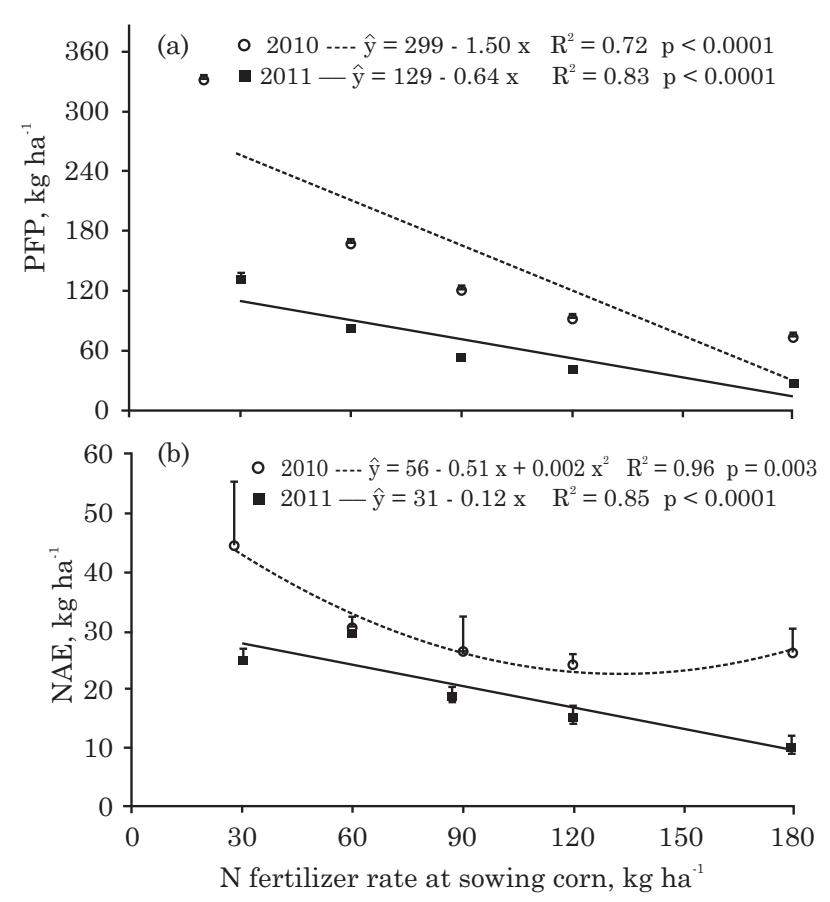

Figure 3. Partial factor productivity (PFP) (a) and agronomic $\mathrm{N}$-use efficiency (ANE) (b) affected by nitrogen fertilizer rates in the 2010 and 2011 growing seasonss. The mean values of the data are shown with error bars that shown the uncertainty of the measurement.

the highest $\mathrm{N}$ rates the $\mathrm{PFP}$ values were similar (Figure 3a). According to Dobermann (2007), under optimal conditions, the PFP typically ranges from 40 to $80 \mathrm{~kg} \mathrm{~kg}^{-1}$. This situation was observed in the 2010 growing season, based on respective equations, at $\mathrm{N}$ rates of 146 and $173 \mathrm{~kg} \mathrm{ha}^{-1}$ and of 77 and $139 \mathrm{~kg} \mathrm{ha}^{-1}$ in 2011, respectively. Therefore, on the basis of the PFP index, the optimum $\mathrm{N}$ rate in 2010 , under favorable climatic conditions, was higher than in 2011, when corn was affected by drought in critical growth stages.

The ANE was assessed by a macro that integrates corn grain yield in a given $\mathrm{N}$ fertilization treatment in relation to a control treatment, divided by the quantity of $\mathrm{N}$ fertilizer input. Snyder \& Bruuselma (2007) suggested the ANE is the index that best reflects the agronomic impact of fertilization. The ANE had a quadratic fit $\left(\mathrm{R}^{2}=0.96 ; \mathrm{p}=0.003\right)$ with $\mathrm{N}$ fertilizer input for the 2010 growing season and a linear fit $\left(R^{2}=0.85 ; p<0.0001\right)$ for 2011 (Figure $\left.3 b\right)$. As the $\mathrm{N}$ fertilizer rate increases ANE decreases. The adjusted mathematical equations indicate that under water stress there is a linear decrease in ANE as fertilizer rates increase, while under favorable climatic conditions high $\mathrm{N}$ rates $\left(90,120\right.$ and $\left.180 \mathrm{~kg} \mathrm{ha}^{-1}\right)$ led to a similar ANE. This suggests that there is a certain buffer capacity, which maintains $\mathrm{N}$ efficiency even at high $\mathrm{N}$ fertilizer rates. The low $\mathrm{N}$ fertilizer rate of $30 \mathrm{~kg} \mathrm{ha}^{-1}$ induced ANE values of 43 and $27 \mathrm{~kg} \mathrm{~kg}^{-1}$ grain yield per $\mathrm{N}$ fertilizer input, for the 2010 and 2011 growing season, respectively. On the other hand, the high $\mathrm{N}$ rate of $180 \mathrm{~kg} \mathrm{ha}^{-1}$ led to ANE of 29 and $9 \mathrm{~kg} \mathrm{~kg}^{-1}$ in the 2010 and 2011 growing season, respectively. As expected, the weather conditions markedly influenced the ANE, so in 2010, the average ANE (24.5 kg kg-1), at an $\mathrm{N}$ rate of $105 \mathrm{~kg} \mathrm{ha}^{-1}$, was $33 \%$ higher than the average ANE $\left(18.4 \mathrm{~kg} \mathrm{~kg}^{-1}\right)$ in 2011.

According to the law of diminishing returns, the increment in corn yield decreases as $\mathrm{N}$ rates increase and thus NUE decreases. In Brazil, Fernandes et al. (2005) and Farinelli \& Borges (2010) reported that the ANE decreased from 80 to $20 \mathrm{~kg} \mathrm{~kg}^{-1}$, when $\mathrm{N}$ fertilizer rates increased from 40 to $180 \mathrm{~kg} \mathrm{ha}^{-1}$. In an experiment carried out in Argentina, it was found that $\mathrm{N}$ rates of 46,150 and $220 \mathrm{~kg} \mathrm{~N}^{-1}$ applied at corn sowing resulted in ANE values of 50, 30 and $20 \mathrm{~kg} \mathrm{~kg}^{-1}$, respectively (Rillo \& Richmond, 2006). According to Dobermann (2007) and Snyder \& Bruulsema (2007), the ANE values were usually between 10 and $30 \mathrm{~kg} \mathrm{~kg}^{-1}$. Under ideal conditions for corn production, the values of this index are above $25 \mathrm{~kg} \mathrm{~kg}^{-1}$. Taking this last value as reference, in 2010 , the $\mathrm{N}$ fertilizer rates below $105 \mathrm{~kg} \mathrm{~N}^{-1}$ were within the optimum range, but in 2011 only the $\mathrm{N}$ rates below $45 \mathrm{~kg} \mathrm{ha}^{-1}$ fit in this range (Figure $3 \mathrm{~b}$ ). In 2010 , the $\mathrm{N}$ rate of $30 \mathrm{~kg} \mathrm{ha}^{-1}$ had the highest ANE $\left(42.4 \mathrm{~kg} \mathrm{~kg}^{-1}\right)$ and the lowest grain yield $\left(9,365 \mathrm{~kg} \mathrm{ha}^{-1}\right)$, among treatments with $\mathrm{N}$ fertilization input (Figure 2b). In 2011, the highest ANE (27.4 $\left.\mathrm{kg} \mathrm{kg}^{-1}\right)$ was also found at an $\mathrm{N}$ rate of $30 \mathrm{~kg} \mathrm{ha}^{-1}$ (Figure $3 \mathrm{~b}$ ) with a yield of 3,981 kg ha-1 (Figure 2b). Boaretto et al. (2007) previously argued that the ANE is variable according to the yield goal. This means, one should not prioritize high ANE at the expense of grain yield, as observed in our study.

\section{Effect of $\mathrm{N}$ fertilization on NRE, PNB and NPE}

Other agronomic fertilizer indices to characterize NUE used in this study were NRE, PNB and NPE (Figure 4). The NRE is an index which determines the quantity of plant $\mathrm{N}$ uptake per unit of $\mathrm{N}$ fertilization. Improving the plant nutritional status is the first goal of $\mathrm{N}$ fertilization, which will result in a higher grain yield under favorable weather conditions during the growing season. Dobermann (2005) and Aita \& Giacomini (2008) argued that NRE depends on the timing of the plant demand with nutrient availability. This synchronism is affected by several factors, above all the method of $\mathrm{N}$ fertilizer application, fertilizer source, fertilizer rate, quantity of residue, type of residue, and weather conditions (Wendling et al., 2007; Amado et al., 2009). Dobermann (2005) summarized data from more than 850 field experiments and found that the NRE of cereal grains is generally around $0.50 \mathrm{~kg} \mathrm{~kg}^{-1}$.

The NRE was affected by $\mathrm{N}$ fertilizer rates in both experimental seasons (Figure 4a). The relationship of 

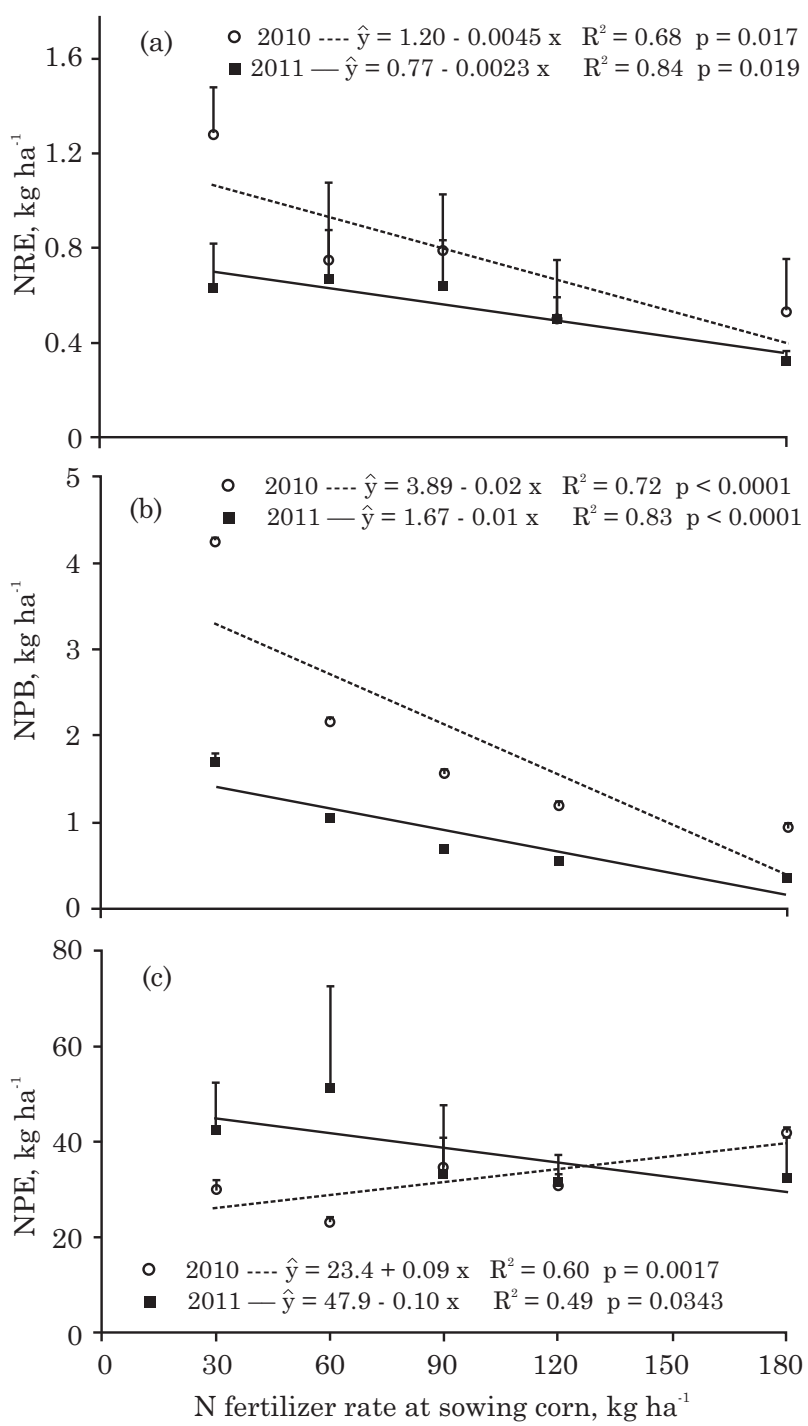

Figure 4. Nitrogen recovery efficiency (NRE) (a), nitrogen partial balance (PNB) (b) and nitrogen physiological efficiency (NPE) (c) affected by nitrogen fertilizer rates in the 2010 and 2011 growing seasons. The mean values of the data are shown with error bars that show the uncertainty of the measurement.

the NRE and $\mathrm{N}$ fertilizer rates was expressed by linear equations $\left(R^{2}=0.68 ; p=0.017\right.$ and $R^{2}=0.84 ; p=0.019$ in the growing seasons of 2010 and 2011, respectively). Thus, the lower $\mathrm{N}$ fertilizer rates resulted in higher $\mathrm{NRE}$ values. The $\mathrm{N}$ rate of $30 \mathrm{~kg} \mathrm{ha}^{-1}$ resulted in NRE values of 1.1 and $0.7 \mathrm{~kg} \mathrm{~kg}^{-1}$ in the 2010 and 2011 growing seasons, respectively. In contrast, high $\mathrm{N}$ rates, e.g., $180 \mathrm{~kg} \mathrm{ha}^{-1}$, resulted in NRE of $0.3 \mathrm{~kg} \mathrm{~kg}^{-1}$ for both growing seasons (Figure 4a). The intermediate $\mathrm{N}$ fertilizer rate of $105 \mathrm{~kg} \mathrm{ha}^{-1}$ resulted in NRE of 0.7 and $0.5 \mathrm{~kg} \mathrm{~kg}^{-1}$ for the 2010 and 2011 growing seasons, respectively. Dobermann (2007) and Snyder \& Bruulsema (2007) reported similar NRE values to those obtained in our study. The authors suggested that NRE values between 0.5 and $0.8 \mathrm{~kg} \mathrm{~kg}^{-1}$ indicate efficient $\mathrm{N}$ management. Therefore, in 2010 and 2011 , the $\mathrm{N}$ fertilization used can be classified as efficient for most N rates. Previously, Yamada (1996) and Sá et al. (1996) reported positive results with N fertilizer application at sowing of no-till corn in Brazil.

Basso \& Ceretta (2000), Lara Cabezas et al. (2005) and Okumura et al. (2011) emphasize that pre-planting $\mathrm{N}$ fertilization is a risky strategy in corn production. If there are intense and frequent rainfall events after fertilization, part of the $\mathrm{N}$ fertilizer input can be lost by leaching or runoff (Tyler \& Thomas, 1977; Basso \& Ceretta, 2000; Wolschick et al. 2003). In our study, in the 2010 season, there was a heavy rainfall $(120 \mathrm{~mm})$ approximately 35 DAS (Figure 1 ). At this event, the corn growth stage was around V4 with only a small quantity of $\mathrm{N}$ uptake. Therefore, it is expected that a large amount of $\mathrm{N}$ was in the mineral form $\left(\mathrm{NO}_{3}{ }^{-}\right)$, which is susceptible to leaching. However, there was no impairment in the efficiency of NRE in the 2010 growing season.

In our study, the analysis of NRE indices showed that the corn $\mathrm{N}$ uptake in 2010 was efficient even at the higher $\mathrm{N}$ rates. On the other hand, for the $\mathrm{N}$ rate of $30 \mathrm{~kg} \mathrm{ha}^{-1}$, NRE was $1.07 \mathrm{~kg} \mathrm{~kg}^{-1}$, which is the double of the inferior limit of the range suggested by Dobermann (2007) and Snyder \& Bruulsema (2007). The high efficiency in $\mathrm{N}$ recovery from low $\mathrm{N}$ rates may be partially explained by the "priming effect" in which the $\mathrm{N}$ fertilizer stimulates soil $\mathrm{N}$ mineralization, thus increasing corn N uptake (Hauck \& Bremner, 1976; Jenkinson et al. 1985; Azam, 1990). Similar results were previously reported in Argentina, where NRE was $1.30 \mathrm{~kg} \mathrm{~kg}^{-1}$ for a low $\mathrm{N}$ rate $\left(46 \mathrm{~kg} \mathrm{ha}^{-1}\right)$ and close to $0.70 \mathrm{~kg} \mathrm{~kg}^{-1}$ for high $\mathrm{N}$ rates (150 and $220 \mathrm{~kg} \mathrm{ha}^{-1} \mathrm{~N}$ ), applied at corn sowing (Rillo \& Richmond, 2006).

In the second growing season, the NRE values were lower than in the first. At the higher $\mathrm{N}$ rates, $\left(>120 \mathrm{~kg} \mathrm{ha}^{-1}\right.$ ) the NRE was below $0.50 \mathrm{~kg} \mathrm{~kg}^{-1}$, indicating low fertilization efficiency. Based on the compiled results of 55 field experiments with corn in the United States, Cassman et al. (2002), reported an NRE of $0.37 \mathrm{~kg} \mathrm{~kg}^{-1}$ for an N rate of $103 \mathrm{~kg} \mathrm{ha}^{-1}$. This result was slightly lower than that obtained in our study in both growing seasons (Figure 4a). Ladha et al. (2005), in 36 corn production trials in Europe, reported an NRE of $0.63 \mathrm{~kg} \mathrm{~kg}^{-1}$ at an $\mathrm{N}$ rate of $100 \mathrm{~kg} \mathrm{ha}^{-1}$. In our study, the $\mathrm{N}$ rate of $90 \mathrm{~kg} \mathrm{ha}^{-1}$ led to NRE values of 0.80 and $0.56 \mathrm{~kg} \mathrm{~kg}^{-1}$, in the 2010 and 2011 growing seasons, respectively. Therefore, the results reported in our study from trials in Paraguay are comparable with those from the international literature.

Figure $4 \mathrm{~b}$ shows the NBP agronomic index, which expresses the quantity of nutrients exported by corn grain per unit of $\mathrm{N}$ fertilizer input. In both years, the data set showed that the relationship of NBP 
with $\mathrm{N}$ fertilizer rates fit to adjusted decreasing linear equations $\left(R^{2}=0.72 ; p<0.0001\right.$ and $R^{2}=0.83$; $\mathrm{p}<0.0001$ in the 2010 and 2011 growing seasons, respectively). According to Snyder \& Bruulsema (2007), NBP values within the range of 0.7 to $1.3 \mathrm{~kg} \mathrm{~kg}^{-1}$ indicate systems with agricultural sustainability characteristics, while values above $1.3 \mathrm{~kg} \mathrm{~kg}^{-1}$ are considered high and indicate that the corn plants are mining the soil $\mathrm{N}$ reserves. Those below $0.7 \mathrm{~kg} \mathrm{~kg}^{-1}$ are considered inefficient, indicating excess of $\mathrm{N}$ input and low $\mathrm{N}$ fertilizer efficiency.

For the N rate of $30 \mathrm{~kg} \mathrm{ha}^{-1}$, the PNB values were 3.3 and $1.4 \mathrm{~kg} \mathrm{~kg}^{-1}$ for 2010 and 2011, respectively. The PNB for the highest $\mathrm{N}$ rate $\left(180 \mathrm{~kg} \mathrm{ha}^{-1}\right)$ corresponded to $0.3 \mathrm{~kg} \mathrm{~kg}^{-1}$ in 2010. In 2010 , the $\mathrm{N}$ rate of $60 \mathrm{~kg} \mathrm{ha}^{-1}$ resulted in PNB values of $2.7 \mathrm{~kg} \mathrm{~kg}^{-1}$, suggesting an imbalance of $\mathrm{N}$ input/output in the agroecosystem. Therefore, in this case, the $\mathrm{N}$ removed at grain harvest was higher than the amount applied via fertilization. Probably, this situation will not be sustained over a long period of time, especially with annual inputs of wheat crop residues (grass with a high $\mathrm{C} / \mathrm{N}$ ratio) that increase $\mathrm{N}$ immobilization. On the other hand, optimum NBP values in the range of 0.7 to $1.3 \mathrm{~kg} \mathrm{~kg}^{-1}$ could be obtained by $\mathrm{N}$ rates in the range of 130 to $160 \mathrm{~kg} \mathrm{ha}^{-1}$ and 40 to $100 \mathrm{~kg} \mathrm{ha}^{-1}$ for the growing seasons of 2010 and 2011, respectively. In these cases, nutrient removal at harvest and $\mathrm{N}$ fertilizer inputs were balanced (Figure 4b). Similar results were previously reported by Rillo \& Richmond (2006) in Argentina, who stated that with a low $\mathrm{N}$ rate at sowing $\left(46 \mathrm{~kg} \mathrm{ha}^{-1}\right)$ the $\mathrm{PNB}$ was high (3.0 kg kg-1) indicating higher $\mathrm{N}$ removal by harvest than the $\mathrm{N}$ input by fertilizer. On the other hand, in their study, the higher $\mathrm{N}$ rates (150 and $220 \mathrm{~kg} \mathrm{ha}^{-1}$ ) improved PNB, which approached $1.0 \mathrm{~kg} \mathrm{~kg}^{-1}$. In our study, a PNB of $1.0 \mathrm{~kg} \mathrm{~kg}^{-1}$ was obtained with $\mathrm{N}$ rates of 145 and $70 \mathrm{~kg} \mathrm{ha}^{-1}$ in the 2010 and 2011 growing seasons, respectively (Figure 4b). García (2009) estimated the average PNB of cereals in Argentina, in the $2007 / 2008$ season, at $1.1 \mathrm{~kg} \mathrm{~kg}^{-1}$.

The NPE is an index that relates the increase in corn grain yield to the increase in the quantity of plant $\mathrm{N}$ uptake from a given $\mathrm{N}$ input compared to a control treatment. In comparison with the other fertilizer efficiency indices, NPE was the most affected by the varying weather conditions in the growing seasons (Figure 4c). For the 2010 growing season, the NPE with the $\mathrm{N}$ fertilizer rates data set was adjusted to a positive linear equation $\left(R^{2}=0.60 ; p=0.0017\right)$ and in 2011 it was adjusted a negative linear equation $\left(R^{2}=\right.$ $0.49 ; \mathrm{p}=0.0343)$.

In our study, treatments with low $\mathrm{N}$ rates, e.g., $30 \mathrm{~kg} \mathrm{ha}^{-1}$ resulted in NPE values from 26.1 to $44.9 \mathrm{~kg} \mathrm{~kg}^{-1}$, respectively, for the growing seasons of 2010 and 2011. In treatments with high $\mathrm{N}$ rate, e.g., $180 \mathrm{~kg} \mathrm{ha}^{-1}$, the NPE values ranged from 39.6 to $29.9 \mathrm{~kg} \mathrm{~kg}^{-1}$ in the growing seasons of 2010 and 2011, respectively. The reference numbers of NPE for cereals, indicating well-balanced $\mathrm{N}$ fertilization, lie in the range of 30 to $60 \mathrm{~kg} \mathrm{~kg}^{-1}$ (Dobermann, 2005). Low NPE values indicate limitations in crop yield related to nutrient deficiency, water stress, temperature stress, plant toxicity, and other limiting factors (Dobermann, 2007). In the first growing season, only the highest $\mathrm{N}$ fertilizer rate was close to the lower limit of the range of the proposed NPE range. In the second growing season, $\mathrm{N}$ rates $<80 \mathrm{~kg} \mathrm{ha}^{-1}$ had higher NPE values than the minimum limit of this range. This result could be partially explained by the fact that the increase in $\mathrm{N}$ rate could increase the water stress level by stimulating vegetative crop growth and thus increasing evapotranspiration (Taiz \& Zeiger, 2009). In the first year, when weather conditions were favorable for corn growth, the average NPE (32.2 $\left.\mathrm{kg} \mathrm{kg}^{-1}\right)$ was also slightly lower than the reference range of NPE. In this case, the plant N uptake could be an important yield-limiting factor. It is highlighted that the maximum grain yield achieved (13 $\mathrm{Mg} \mathrm{ha}^{-1}$ ) could demand a plant $\mathrm{N}$ uptake as high as $230 \mathrm{~kg} \mathrm{ha}^{-1}$ (Figure 2a).

The general analysis of $\mathrm{N}$ fertilizer efficiency indices investigated in our study showed that the highest $\mathrm{N}$ rate $\left(180 \mathrm{~kg} \mathrm{ha}^{-1}\right)$ in the first growing season resulted in the highest grain yield and showed satisfactory values of NPE, NRE, ANE and NBP indices as well, indicating high NUE in the agroecosystem. However in the 2011 growing season, the maximum NUE was achieved with a low $\mathrm{N}$ rate (60 kg ha-1), which provided adequate values of NPE and ANE, and an index of NBP that suggested a balance between nutrient input and output by crop harvest (Figure 4). Thus, $\mathrm{N}$ fertilization at corn sowing was an efficient nutrient management system when weather conditions were favorable for plant growth (2010 growing season). We emphasize the large differences in optimum $\mathrm{N}$ fertilization between the growing seasons (180 and $60 \mathrm{~kg} \mathrm{ha}^{-1}$ in 2010 and 2011 , respectively), due to the weather conditions. This fact complicates the decision-making process of the quantity of $\mathrm{N}$ fertilizer to be applied at sowing to ensure a high NUE, since the weather conditions that will prevail during the growing season are unknown at planting.

\section{CONCLUSIONS}

1. The response of corn grain yield to $\mathrm{N}$ fertilization at sowing was influenced by the prevailing weather conditions during crop growing season. Under favorable weather conditions for crop growth, the relationship of grain yield and $\mathrm{N}$ fertilizer was linear, showing high $\mathrm{N}$ response. In contrast, under water stress, this relationship was quadratic, indicating moderate $\mathrm{N}$ response.

2. Based on the agronomic indices of $\mathrm{N}$ efficiency investigated in this study, the highest $\mathrm{N}$ rate $\left(180 \mathrm{~kg} \mathrm{ha}^{-1}\right)$ in the first growing season was the most 
efficient. Contrarily, in the second growing season, the most efficient $\mathrm{N}$ fertilizer rate was $60 \mathrm{~kg} \mathrm{ha}^{-1}$, i.e., three times lower than in the first season.

3. The strategy of full $\mathrm{N}$ fertilization at corn sowing is not recommended for southern Paraguay. Erratic weather conditions make the prediction of the optimum $\mathrm{N}$ rate at the time of sowing impossible.

\section{LITERATURE CITED}

ACOSTA, J.A.A.; AMADO, TJ.C.; NEERGAARD, A.; VINTHER, M.; SILVA, L.S.S \& NICOLOSO, R.S. Effect of ${ }^{15} \mathrm{~N}$-labeled hairy vetch and nitrogen fertilization on maize nutrition and yield under no-tillage. R. Bras. Ci. Solo, 35:1337-1345, 2011.

AITA, C. \& GIACOMINI, S.J. Decomposição e liberação de nitrogênio de resíduos culturais de plantas de cobertura de solo solteiras e consorciadas. R. Bras. Ci. Solo, 27:601$612,2003$.

AITA, C. \& GIACOMINI, S.J. Nitrato no solo com a aplicação de dejetos líquidos de suínos no milho em plantio direto. R. Bras. Ci. Solo, 32:2101-2111, 2008.

AMADO, T.J.C.; MIELNICZUCK, J. \& AITA, C. Recomendação de adubação nitrogenada para o milho no RS e SC adaptada ao uso de culturas de cobertura do solo, sob Sistema de Plantio Direto. R. Bras. Ci. Solo, 26:241-248, 2002.

AMADO, T.J.C.; MIELNICZUK, J. \& FERNANDES, S.B.V. Leguminosas e adubação mineral como fontes de nitrogênio para o milho em sistemas de preparo do solo. R. Bras. Ci. Solo, 24:179-189, 2000.

AMADO, T.J.C.; PES, L.Z.; LEMAINSKI, C.L. \& SCHENATO, R.B. Atributos químicos e físicos de Latossolos e sua relação com os rendimentos de milho e feijão irrigados. R. Bras. Ci. Solo, 33:831-843, 2009.

AMARAL FILHO, J.P.R.; FORNASIERI FILHO, D.; FARINELLI, R. \& BARBOSA, J.C. Espaçamento, densidade populacional e adubação nitrogenada na cultura do milho. R. Bras. Ci. Solo, 29:467-473, 2005.

AZAM, F. Comparative effects of organic and inorganic nitrogen sources applied to a flooded soil on rice yield and availability of N. Plant Soil, 125:255-262, 1990.

BASSO, C.J. \& CERETTA, C.A. Manejo do nitrogênio no milho em sucessão a plantas de cobertura de solo sob plantio direto. R. Bras. Ci. Solo, 24:905-915, 2000.

BAYER, C.; DIECKOW, J.; AMADO, T.J.C.; ELTZ, F.L.F. \& VIEIRA, F.C.B. Cover crop effects increasing carbon storage in a subtropical no-till sandy acrisol. Commun. Soil Sci. Plant Anal., 40:1499-1511, 2009.

BAYER, C.; MIELNICZUK, J. \& PAVINATO, A. Sistemas de manejo do solo e seus efeitos sobre o rendimento do milho. Ci. Rural, 28:23-28, 1998.

BOARETTO, A.; MURAOKA, T. \& TRIVELIN, P. Uso eficiente de nitrogênio nos fertilizantes convencionais. Inf. Agron., 120:13-14, 2007.
BORTOLINI, C.G.; SILVA, P.R.F.; ARGENTA, G. \& FORSTHOFER, E.L. Rendimento de grãos de milho cultivado após aveia-preta em resposta a adubação nitrogenada e regime hídrico. Pesq. Agropec. Bras., 36:1101-1106, 2001.

BERTOLINI, E.V.; GAMERO, C.A.; SALATA, A.C. \& PIFFER, C.F. Antecipação da adubação de semeadura do milho em dois sistemas de manejo do solo. R. Bras. Ci. Solo, $32: 2355-2366,2008$

CAMARA PARAGUAYA DE EXPORTADORES DE CEREALES Y OLEAGINOSAS - CAPECO. Available: <http://www.capeco.org.py>. Accessed: Nov. 03, 2011.

CANTARELLA, H.; LERA, F.L.; BOLONHEZI, D.; LARA CABEZAS, W.A.R. \& TRIVELIN, P.C.O. Antecipação de $\mathrm{N}$ em milho em sistema de plantio direto usando $15 \mathrm{~N}$ uréia. In: CONGRESSO BRASILEIRO DE CIÊNCIA DO SOLO. 29., 2003. Anais... Ribeirão Preto, Sociedade Brasileira de Ciência do Solo, 2003. CD-ROM

CANTARELLA, H. \& MONTEZANO, F.Z. Nitrogênio e enxofre. In: PROCHNOW, L.I.; CASARIN, V. \& STRIPP, S.R., eds. Boas práticas para o uso eficiente de fertilizantes nutrientes. Piracicaba, International Plant Nutrition Institute, 2010. p.5-46.

CASSMAN, K.G.; DOBERMANN, A. \& WALTERS, D.T. Agroecosystems, nitrogen-use efficiency, and nitrogen management. R. Ambio, 31:132-140, 2002.

CERETTA, C.A.; BASSO, C.J.; FLECHA, A.M.T.; PAVINATO, P.S.; VIEIRA, F.C.B. \& MAI, M.E.M. Manejo da adubação nitrogenada na sucessão aveia preta/milho, no sistema plantio direto. R. Bras. Ci. Solo, 26:163-171, 2002.

COELHO, A.M.; CRUZ, J.C. \& PEREIRA FILHO, I.A. Rendimento de milho no Brasil: Chegamos ao máximo. In: SIMPÓSIO DE ROTAÇÃO SOJA/MILHO NO PLANTIO DIRETO, 3., Piracicaba, 2002. Anais... Piracicaba, Escola Superior de Agricultura Luiz de Queiroz, 2002. CD-ROM

COELHO, A.M.; FRANÇA, G.E.; BAHIA, A.F.C. \& GUEDES, G.A.A. Balanço de nitrogênio $\left({ }^{15} \mathrm{~N}\right)$ em um Latossolo Vermelho-Escuro, sob vegetação de cerrado, cultivado com milho. R. Bras. Ci. Solo, 15:187-193, 1991.

COOKE, G.W. Maximizing fertilizer efficiency by overcoming constraints to crop growth. J. Plant. Nutr., 10:1357-1369, 1987.

DOBERMANN, A. Nitrogen use efficiency - State of the art. In: IFA INTERNATIONAL WORKSHOP ON ENHANCED-EFFICIENCY FERTILIZERS, Frankfurt, 2005. Proceedings... Frankfurt, 2005. p.28-30.

DOBERMANN, A. Nutrient use efficiency - Measurement and management. In: WORKSHOP ON FERTILIZER BEST MANAGEMENT PRACTICES, Bélgica, 2007. 9p.

FARINELLI, R. \& BORGES, L. Produtividade e eficiência agronômica do milho em função da adubação nitrogenada e manejos do solo. R. Bras. Milho Sorgo, 9:135-146, 2010. 
FERNANDES, F.C.S.; BUZETTI, S.; ARF, O. \& ANDRADE, J.A.C. Doses, eficiência e uso de nitrogênio por seis cultivares de milho. R. Bras. Milho Sorgo, 4:195-204, 2005.

FERREIRA, D.F. Programa SISVAR.exe: Sistema de análise de variância. Lavras, Universidade Federal de Lavras, 2010.

FONTOURA, S.M.V. \& BAYER, C. Adubação nitrogenada para alto rendimento de milhho em plantio direto na região Centro-Sul do Paraná. R. Bras. Ci. Solo, 33:1721-1732, 2009 .

GADIOLI, J.L.; DOURADO-NETO, D.; GARCÍA, A.G. \& BASANTA, M.D.V. Temperatura do ar, rendimento de grãos de milho e caracterização fenológica associada à soma calórica. Sci. Agric., 57:377-383, 2000.

GARCÍA, F. Eficiencia de uso de nutrientes y mejores prácticas de manejo para la nutrición de cultivos. In: SIMPOSIO FERTILIDAD, 2009, Alto Rosario. Proceedings... Alto Rosario, International Plant Nutrition Institute, 2009. p.9-19.

GAVA, G.J.C. Compartimentalização do nitrogênio no sistema solo-planta na implantação da semeadura direta no ciclo da cultura do milho. Piracicaba, Centro de Energia Nuclear na Agricultura, Universidade de São Paulo, 2002. 125p. (Tese de Doutorado)

GOMES, R.F.; SILVA, A.G.; ASSIS, R.L. \& PIRES, F.R. Efeito de doses e da época de aplicação de nitrogênio nos caracteres agronômicos da cultura do milho sob plantio direto. R. Bras. Ci. Solo, 31:931-938, 2007.

GROSS, M.R.; von PINHO, R.G. \& BRITO, A.H. Adubação nitrogenada, densidade de semeadura e espaçamento entre fileiras na cultura do milho em sistema plantio direto. R. Ci. Agrotec., 30:387-393, 2006.

HAUCK, R.D. \& BREMNER, J.M. Use of tracers for soil nitrogen research. Adv. Agron., 28:219-266, 1976.

JENKINSON, D.S. Interactions between fertilizer nitrogen and soil nitrogen - the so-called 'priming' effect. Eur. J. Soil Sci., 6:425-444, 1985.

LADHA, J.K.; PATHAK, H.; KRUPNIK, T.J.; SIX, J. \& VAN KESSEL, C. Efficiency of fertilizer nitrogen in cereal production: Retrospects and prospects. Adv. Agron., 87:85186, 2005.

LARA CABEZAS, W.A.R.; ARRUDA, M.R.; CANTARELLA, H.; PAULETTI, V.; TRIVELIN, P.C.O. \& BENDASSOLLI, J.A. Imobilização de nitrogênio da ureia e do sulfato de amônio aplicado em pré-semeadura ou cobertura na cultura de milho, no sistema plantio direto. R. Bras. Ci. Solo, 29:215-226, 2005.

MELGAR, R. Fertilización en el Corn Belt. Es tan diferente de lo que hacemos aqui? R. Fert., 5:21-31, 2006.

NASCIMENTO, F.M.; BICUDO, S.J.; FERNANDES, D.M.; RODRIGUES, J.G.L.; FERNANDES, J.C. \& FURTADO, M.B. Efeito da antecipação da adubação nitrogenada na cultura do milho em sistema plantio direto. R. Bras. Ci. Agron., 7:1-8, 2012.

OKUMURA, R.S.; MARIANO, D.C. \& ZACCHEO, P.V.C. Uso de fertilizante nitrogenado na cultura do milho: uma revisão. R. Bras. Tec. Aplic. Ci. Agron., 4:226-244, 2011.
PAVINATO, P.S.; CERETTA, C.A.; GIROTTO, E. \& MOREIRA, I.C.L. Nitrogênio e potássio em milho irrigado: análise técnica e econômica da fertilização. Ci. Rural, 38:358-364, 2008.

RAMBO, L.; SILVA, P.R.F.; STRIEDER, M.L.; SILVA, A.A.; SANGOI, L. \& VIEIRA. V.M. Índices nutricionais de $\mathrm{N}$ e produtividade de milho em diferentes níveis de manejo e de adubação nitrogenada. Pesq. Agropec. Bras., 46:390397, 2011.

RAUN, W.R. \& JOHNSON, G.V. Improving $\mathrm{N}$ use efficiency for cereal production. Agron. J., 91:357-363, 1999.

RILLO, S.N. \& RICHMOND, P.B. Evaluación de tres criterios de fertilización nitrogenada en el cultivo de maiz en siembra directa en un suelo hapludol. In: NATIONAL CONGRESS OF AAPRESID, 16., Rosario, 2006. Anais... Rosário, AAPRESID, 2006. p.78-84.

SÁ, J.C.M. Manejo do nitrogênio na cultura do milho no sistema plantio direto. Passo Fundo, Aldeia Norte, 1996. 24p.

SALL, J.; CREIGHTON, L. \& LEHMAN, A. JMP start statistics: a guide to statistics and data analysis using JMP and JMP IN software. 3.ed. Cary, Duxbury Press, 2005. 580p.

SCHMIDT, G. Cuenca del Arroyo Capiibary, simulación del flujo subterráneo. In: PROYECTO SAG-PY. Uso Sostenible del Sistema Acuífero Guaraní en la Región Oriental del Paraguay, 7. Asunción, SEAM/BGR, 2009. 30p.

SOUZA, L.C.F.; GONÇALVES, M.C.; ALVES SOBRINHO, T.; FEDATTO, E.; ZANON, G. D. \& HASEGAWA, E.K.B. Culturas antecessoras e adubação nitrogenada na produtividade de milho em plantio direto irrigado. R. Bras. Milho Sorgo, 2:55-62, 2003.

SNYDER, C.S. \& BRUULSEMA, T.W. Nutrient use efficiency and effectiveness in North America: Indices of Agronomic and Environmental Benefit. Norcross, International Plant Nutrition Institute, 2007. 4p.

TAIZ, L. \& ZEIGER, E. Fisiologia vegetal. 4.ed. Porto Alegre, Artmed, 2009. 819p.

TEDESCO, M.J.; GIANELLO, C.; BISSANI, C.A.; BOHNEN, H. \& VOLKWEISS, S.J. Análise de solo, plantas e outros materiais. 2.ed. Porto Alegre, Universidade Federal do Rio Grande do Sul, 1995. 174p.

TYLER, D.D. \& THOMAS, G.W. Lysimeter measurements of nitrate and chloride losses from soil under conventional and no-tillage corn. J. Environ. Qual., 6:63-66, 1977.

WENDLING, A.; ELTZ, F.L.F.; CUBILLA, M.M.; AMADO, T.J.C.; MIELNICZUK, J. \& LOVATO, T. Recomendação de adubação nitrogenada para trigo em sucessão ao milho e soja sob sistema plantio direto no Paraguai. R. Bras. Ci. Solo, 31:985-994, 2007.

WOLSCHICK, D.; CARLESSO, R.; PETRY, M.T. \& JADOSKI, S.O. Adubação nitrogenada na cultura do milho no sistema plantio direto em ano com precipitação pluvial normal e com "El Niño". R. Bras. Ci. Solo, 27:461-468, 2003.

YAMADA, T. Adubação nitrogenada no milho: Quanto, como e quando aplicar. Piracicaba, Potafos, 1996. p.15. (Informativo Agronômico, 47)

YAMADA, T. \& ABDALLA, S.R.S. -Como melhorar a eficiência da adubação nitrogenada do milho? Piracicaba, Potafos, 2000. p.5. (Informativo Agronômico, 91) 